\title{
THE FIRST LAW OF THERMODYNAMICS ANALYSIS OF TRANSPORTERS INVOLVED IN THE GLUTAMATE/GABA-GLUTAMINE CYCLE
}

\author{
Mert GUR*, Sema Zeynep YILMAZ**,+ ve Elhan TAKA***,+ \\ Department of Mechanical Engineering, Faculty of Mechanical Engineering, Istanbul Technical University, \\ 34437 Beyoğlu, Istanbul, Turkey \\ *gurme@itu.edu.tr, ORCID: 0000-0003-0983-4397 (Corresponding author) \\ **yilmazse17@itu.edu.tr, ORCID: 0000-0002-4839-3777 \\ ***taka17@itu.edu.tr, ORCID: 0000-0002-4017-5839 \\ +These authors contributed equally.
}

(Geliş Tarihi: 18.05.2021, Kabul Tarihi: 17.10.2021)

\begin{abstract}
The glutamine-glutamate/GABA cycle (GGC) is a sequence of events that provides replenishment of the neurotransmitter pool of glutamate in order to maintain neurotransmitter homeostasis. In the GGC, glutamate or GABA molecules are released from neurons and subsequently taken up into astrocytes. Astrocytes convert glutamate or GABA molecules into glutamine and release them into the synapse. Glutamine molecules are taken up by neurons to be used as a precursor for the synthesis of glutamate or GABA. The transport of these molecules across the membranes of neurons and astrocytes is facilitated by transporter proteins. Each of these transporter proteins is a biomolecular machine; they operate on thermodynamic cycles and convert part of the supplied energy input into useful work output. Energy harnessed from the translocation of molecules/ions down their electrochemical gradient is converted into mechanical useful work translocating molecules/ions against their electrochemical gradient. Conservation of energy principle was applied and thermodynamic first law efficiencies, showing how much of the energy input per cycle is converted into useful work, were evaluated for the thermodynamic cycles of EAAT, ASCT2, $\mathrm{B}^{0} \mathrm{AT} 2, \mathrm{SA}, \mathrm{SN}$, and GABA transporters involved in the GGC. Neurotransmitter concentrations in the synapse change upon signal arrival and subsequently return to resting levels, causing transporters to operate under various first law efficiencies. Range of first law efficiencies for EAAT (for glutamate transport), ASCT2, B ${ }^{0}$ AT2, SA SN, GABA (forward mode) were calculated as 60-85\%, 46-78\%, 61-89\%, 61-89\%, 55-80\%, and 54-76\%, respectively. Efficiency values obtained for these transporters are much higher than those of the macro-scaled heat engines we encounter in our daily lives. Furthermore, EAAT showed larger thermodynamic first law efficiency for glutamate transport than aspartate transport, which takes place with a maximum efficiency of $45 \%$. Thus, suggesting the possibility that transport of different substrates by the same transporter may take place with different efficiencies.
\end{abstract}

Keywords: Thermodynamics, First Law Efficiency, Biomolecular Machines, Glutamine-Glutamate/GABA Cycle, EAAT, GABA, Glutamine, Glutamate, Transporter, Neurotransmitter and Ion Concentrations.

\section{GLUTAMAT/GABA-GLUTAMIN ÇEVRIMINDE GÖREV ALAN TAŞIYICI PROTEINNLER İÇIN TERMODINAMIĞİN BİRINCI YASA ANALIZİ}

Özet: Glutamin-glutamat/GABA çevrimi (GGC), nörotransmiter homeostazını sürdürmek için glutamatın nörotransmitter havuzunun yenilenmesini sağlayan bir olaylar dizisidir. GGC'de, glutamat veya GABA molekülleri nöronlardan salınır ve ardından astrositlere alınır. Astrositler, glutamat veya GABA moleküllerini glutamine dönüştürür ve onları sinapsa salar. Glutamin molekülleri, glutamat veya GABA sentezi için bir öncü olarak kullanılmak üzere nöronlar tarafından alınır. Bu moleküllerin, nöronların ve astrositlerin hücre zarları boyunca taşınması, taşıyıcı proteinler tarafından sağlanmaktadır. Söz konusu taşıyıcı proteinler biyomoleküler makinalar olup termodinamik çevrimlerde çalışmakta ve giren enerjinin bir kısmını yararlı işe dönüştürmektedir. Moleküllerin/iyonların elektrokimyasal gradyanı yönündeki taşınımından elde eldilen enerji, protein içerisinde mekanik yararlı işe dönüştürülerek moleküllerin/iyonların elektrokimyasal gradyanlarının tersine taşınımı için kullanılmaktadır. Çalışmamızda enerjinin korunumu yasası uygulanmıştır ve çevrim boyunca sisteme giren enerjinin ne kadarının yararlı işe dönüştürüldüğünü gösteren termodinamik birinci yasa verimlilikleri, GGC'de bulunan EAAT, ASCT2, B ${ }^{0} \mathrm{AT} 2, \mathrm{SA}$, SN ve GABA taşıyıcıları için hesaplanmıştır. Sinapstaki nörotransmitter konsantrasyonları, sinyal iletimiyle değişmekte ve daha sonra bazal seviyelerine geri dönmektedir. Bu ise taşıyıcıların konsatrasyonlara bağlı olarak değişen birinci yasa verimlilik değerleriyle çalışmalarına sebep olmaktadır. EAAT (glutamat taşınımı için), ASCT2, B0AT2, SA SN, GABA (ileri yönde taşınım) için birinci yasa verimliliklerinin aralıkları sırasıyla \%6085, \%46-78, \%61-89, \%61-89, \%55-80 ve \%54-76 olarak hesaplanmıştır. Taşıyıcı proteinler için elde edilen 
verimlilik değerleri, günlük hayatımızda karşılaştığımız makro ölçekli 1sı makinalarına nazaran çok yüksektir. Buna ek olarak, EAAT proteinin glutamat taşınımını, maksimum $\% 45$ değerinde birinci yasa verimliliğiyle gerçekleşen aspartat taşınımına göre, daha yüksek verimlilikle gerçekleştirdiği belirlenmiştir. Dolayısıyla, farklı substratların aynı taşıyıcı tarafından taşınımının farklı verimliliklerle gerçekleşebileceği ortaya konulmuştur.

Anahtar Kelimeler: Termodinamik, Birinci Yasa Verimliliği, Biyomoleküler Makinalar, Glutamin-Glutamat/GABA çevrimi, EAAT, GABA, Glutamin, Glutamat, Taş̧ı1ıı, Nörotransmitter ve iyon konsantrasyonları.

\section{NOMENCLATURE}

$\begin{array}{ll}\text { ASCT } & \text { Alanine/Serine/Cysteine Transporter } \\ \text { Asp } & \text { Aspartate } \\ \text { ATP } & \text { Adenosine Triphosphate } \\ \text { B }^{0} \text { AT } & \text { B }^{0} \text { Neutral Amino Acid Transporter } \\ \text { Ca } & \text { Calcium } \\ \text { ClChloride } & \\ \text { CNS } & \text { Central Nervous System } \\ \text { DAT } & \text { Dopamine Transporter } \\ \text { EAAT } & \text { Excitatory Amino Acid Transporters } \\ \text { EC } & \text { Extracellular } \\ \text { F } & \text { Faraday Constant } \\ \text { GAT } & \text { GABA Transporter } \\ \text { GABA } & \text { Gamma-Aminobutyric Acid } \\ \text { GGC } & \text { Glutamine-Glutamate/GABA Cycle } \\ \text { Gln } & \text { Glutamine } \\ \text { Glu } & \text { Glutamate } \\ \text { GlyT } & \text { Glycine Transporter } \\ \text { H } & \text { Hydrogen } \\ \text { IC } & \text { Intracellular } \\ \text { K } & \text { Potassium } \\ \text { LAT } & \text { Light Subunits of Amino Acid } \\ & \text { Transporters } \\ \text { Na } & \text { Sodium An Aar } \\ \text { R } & \text { Universal Gas Constant } \\ \text { SA } & \text { System A } \\ \text { SERCA } & \text { Sarco/Endoplasmic Reticulum } \\ \text { SLC } & \text { ATPase } \\ \text { SN } & \text { Solute Carrier } \\ \text { SNAT } & \text { System N } \\ & \text { Sodium-Coupled Neutral Amino Acid } \\ & \text { Transporter } \\ & \end{array}$

\section{INTRODUCTION}

Glutamine is the most abundant amino acid in human body and has a central place in the metabolism of all major macromolecules in mammalian cells (Bhutia and Ganapathy, 2016). Glutamine participates in several pathways, such as scavenging of ammonia as a nitrogen donor, maintenance of redox state, and the glutamineglutamate/GABA cycle (GGC) (Schousboe and Sonnewald, 2016). The GGC is a crucial pathway in the brain for production of excitatory neurotransmitter glutamate and the inhibitory neurotransmitter GABA in neurons and astrocytes, thus making GGC essential for normal functioning of brain (Schousboe and Sonnewald, 2016) and maintaining proper neurotransmission (Cabrera-Pastor et al., 2019). In the GGC, glutamine acts as a precursor for the synthesis of the biologically important molecules glutamate and gamma-aminobutyric acid (GABA) (Bhutia and Ganapathy, 2016). Glutamate is the major molecule for excitatory transmission (Zhou and Danbolt, 2014) whereas GABA is the essential molecule for inhibitory transmission in the central nervous system (CNS) (Owens and Kriegstein, 2002). Due to the essential roles of these molecules in information transfer between neurons and astrocytes, controlling their spatiotemporal levels in the synapse is of utmost importance.

The GGC (Figure 1) comprises two sub-cycles; (i) the glutamate-glutamine cycle and (ii) the GABA-glutamine cycle (Walls et al., 2015). The glutamate-glutamine cycle can be summarized as follows: upon a signal arrival, glutamate is released from presynaptic neurons to synapse and activate receptors and channels on postsynaptic neurons. Subsequently, glutamate is rapidly removed from the synaptic cleft into the surrounding astrocytes via glutamate transporters located on the cell membranes (Bak et al., 2006). Glutamate is then converted to glutamine in astrocytes, decreasing the total amount of glutamate. To replenish the neurotransmitter pool of glutamate, an intensive glutamine flow from astrocytes to glutamatergic neurons must take place. Thus, glutamine is taken up into the glutamatergic neurons and converted into glutamate (Walls et al., 2015). Glutamate is then sequestered in synaptic vesicles to be made available for secretion. This completes the glutamate-glutamine cycle. The GABA-glutamine cycle can be summarized as follows: glutamine released by astrocytes is taken up by GABAergic neurons and converted to GABA (Walls et al., 2015). GABA is released from GABAergic neurons and taken up into astrocytes via GABA transporters located on the cell membranes, where it is converted to glutamine (Bak et al., 2006). Thus, the GABA-glutamine cycle becomes completed.

Transporters involved in the GGC belong to the solute carrier (SLC) family. SLC family members transport a great variety of solutes across the membrane, including inorganic ions, amino acids, sugars, and relatively complex organic molecules (Höglund et al., 2010). The SLC family contains 52 subfamilies with more than 400 members in total (Schlessinger et al., 2013), including secondary active transporters, ion channels, and other membrane proteins, which do not have the transport capability on their own but interact with other SLC members to form functional heterodimers. 


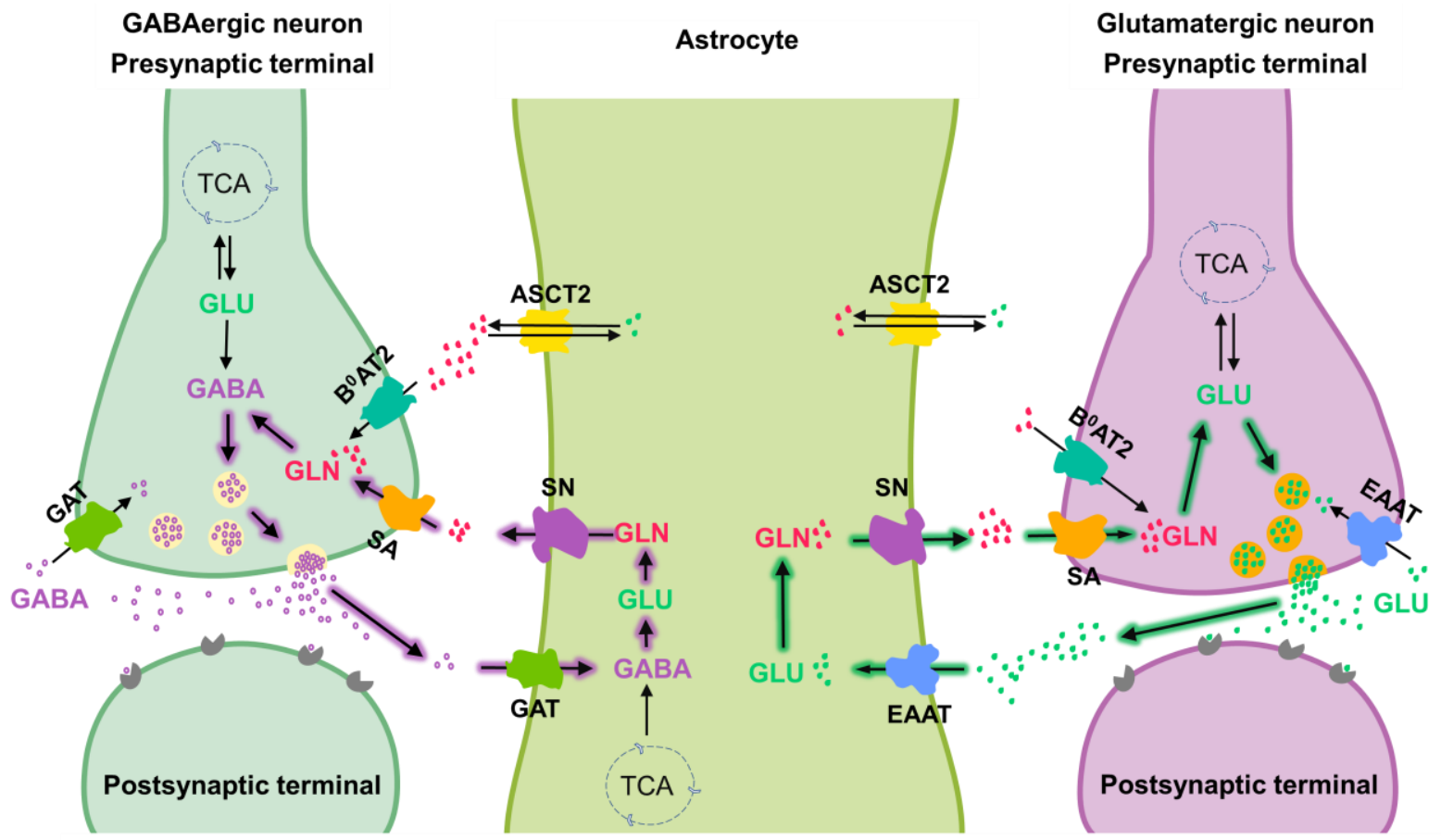

Figure 1. The glutamine-glutamate/GABA cycle. A glutamatergic neuron, a GABAergic neuron, an astrocyte, transporters involved in GGC and the neurotransmitters carried by them are shown schematically. Arrows highlighted in purple and green represent the GABA-glutamine cycle and the glutamate-glutamine cycle, respectively. Glutamate/GABA molecules are released from neurons into synapse. Astrocytes take up these molecules and convert into glutamine. Glutamine is released into the synapse and taken up by neurons, where it is used as a precursor for glutamate/GABA synthesis. Schematic representations of proteins were inspired by their crystal structures if present.

SLC family transporters have been associated with various rare and common diseases, making them prominent targets for novel therapeutic strategies (Lin et al., 2015). SLC family transporters participating in GGC are secondary active transporters. During GGC, these transporters perform transport of glutamine, glutamate, and GABA across the cell membrane by harnessing the energy of electrochemical ion gradients.

For glutamate transport, five glutamate transporters, also termed excitatory amino acid transporters (EAATs), from the SLC1 family have been identified: EAAT1 (GLAST), EAAT2 (GLT-1) EAAT3 (EAAC1), EAAT4 and EAAT5 (Danbolt et al., 2016). EAAT1 and EAAT2 are expressed in astrocytes, while the other three are expressed in neurons (Danbolt, 2001). For glutamine transport, the families of SLC1, SLC6, SLC7, and SLC38 have been characterized as glutamine transporters (Bhutia and Ganapathy, 2016). Among the SLC1 family members, the ASC (alanine/serine/cysteine) transporters function as exchangers for small neutral amino acids (Kanai et al., 2013). There are two isoforms of the ASC transporter, known as ASCT1 and ASCT2 having different substrate selectivity. ASCT1 is mainly responsible for transport of L-serine (Sakai et al., 2003) and L-trans-4 hydroxyproline (Pinilla-Tenas et al., 2003) in astrocytes. ASCT2, on the other hand, performs antiport of glutamine with neutral amino acids in a $\mathrm{Na}^{+}-$ dependent manner in neurons and astrocytes (Bröer et al., 1999). In addition, ASCT2 also functions as a glutamine/glutamate exchanger in astrocytes (Oppedisano et al., 2007). Another family SLC6, includes neutral amino acid transporters such as $\mathrm{B}^{0} \mathrm{AT} 2$, and $\mathrm{B}^{0} \mathrm{AT} 1$ which are able to transport glutamine (Pramod et al., 2013). Among the SLC7 family members, the light subunits of amino acid transporters called LATs show a low-affinity and high-capacity glutamine uptake activity in astrocytes and neurons (Heckel et al. 2003). SCL38 family of transporters, known as sodium-coupled neutral amino acid transporters (SNATs), have two different systems, defined as system A (SA) being capable of transport alanine and system $\mathrm{N}(\mathrm{SN})$ that is able to transport amino acids with nitrogen in its side chain. SA includes members called SNAT1, SNAT2, SNAT4, and SNAT8 (Ortega and Schousboe, 2017). Among those, SNAT1 and SNAT2 are located on neurons and perform glutamine uptake from synapse. SN comprises SNAT members SNAT3, SNAT5, and SNAT7. SN has a transport activity specific for glutamine, asparagine and histidine (Nakanishi et al., 2001). In addition, SNAT5 is able to transport alanine and serine (Bröer, 2014). For GABA transport, four transporters belonging the SLC6 family are characterized as GABA transporters, known as GAT1, GAT2, GAT3, and GAT4 (Ortega and Schousboe, 2017). GAT1 and GAT2 are expressed in both neurons and astrocytes (Schousboe et al., 2004), whereas GAT3 and GAT4 are predominantly expressed in astrocytes. 
Transporter proteins show similarities to various macroscaled machines that we encounter in our daily life. They convert part of the supplied energy into useful work, just like their macro-scaled counterparts. For a great part of macro-scaled machines, called heat engines, the energy input is the heat generated from various types of fuels (gasoline, coal, $\mathrm{H}_{2}$ etc.). Transporter proteins, on the other hand, use various types of energy sources including breakage/formation of covalent bonds, oxidation/ reduction reactions, and translocation of ions down their electrochemical gradient, to produce work. Transporter proteins operate on thermodynamic/mechanical cycles and return to their initial state at the end of the process, as it is the case for their macro-scaled counterparts. For each cycle, there is an energy input and an energy output, which is usually work. Transporter proteins involved in GGC utilize the energy harnessed from the translocation of molecules/ions down their electrochemical gradient as energy input. These energy inputs are converted by the transporter proteins into useful work translocating molecules/ions against their electrochemical gradient.

The first law of thermodynamics, also known as the conservation of energy principle, provides a rigid base for studying the relationships between the energy input and output for during a cycle (Cengel and Boles, 2008). The second law of thermodynamics can be effectively used to determine the theoretical limits for the performance of widely used engineering systems, such as heat engines and refrigerators as well as predicting the degree of completion of chemical reactions. Although the first law analysis of heat engines (and also other types of macro-scaled machines) have been widely and thoroughly performed, only a very limited number of first law analyses was performed for micro-scaled thermodynamic systems. For proteins, such studies are limited to rotary motor protein F1-ATPase with a probe particle attached to it inside a solution (Zimmermann and Seifert, 2012) ensemble of membranes containing $\mathrm{Ca}^{2+}$ ATPases (Kjelstrup et al., 2008), and two primary active transporters: the sodium-potassium pump and SERCA (both of which are ATP-powered pumps), and a total of four secondary active transporters: dopamine transporter (DAT), glutamate transporter, glycine transporters (GlyT) 1 and 2 (Gur et al., 2019). Thus, except for a few proteins, the energy conversion efficiency has not been yet explicitly formulated.

In this study, we performed the first law of thermodynamics analysis of transporters involved in the GGC, specifically EAAT, ASCT2, B ${ }^{0}$ AT2, SA, SN, and GABA transporters. Using the experimentally reported ion and neurotransmitter concentrations in the literature, thermodynamic first law efficiencies for these transporters were evaluated. Our results showed that first law efficiencies of transporters involved in GCC change with neurotransmitter concentrations and the maximum efficiencies observed for each transporter ranged between $45-89 \%$.

\section{METHODOLOGY}

\section{The First Law Analysis of Transporter Proteins}

The detailed formulation of the first law of thermodynamics analysis for a single membrane protein can be found in our recent study (Gur et al., 2019). A transporter protein involved in GGC is selected as the thermodynamic system of interest and the region within the protein is selected as the control volume, which is also called an open system. In Figure 2, boundary of the control volume is represented schematically. Both mass and energy can cross the boundary of the control volume. Energy transfer into the system is in the form of the energy released due to the translocation of molecules/ions down their electrochemical gradients across the membrane. Energy transfer out of the system can be in the form of work or heat. The function of transporter proteins in the GGC is to translocate molecules/ions across the membrane against their electrochemical gradients. Thus, for the transporter protein to perform its function there is a certain work requirement that is referred to as useful work, $W_{\text {useful }}$. The work requirement depends on the intra- and extracellular concentrations of the transported molecules/ions and their charges. Furthermore, since the transporter protein changes its structure during its thermodynamic cycle there is a work performed to move the system boundary against external forces. This work is denoted as boundary work, $W_{\text {boundary }}$. As the system boundaries move at finite rate, a pressure difference across the system boundary is always required to move the boundaries. Moreover, as the boundary moves at a finite rate in an environment, there will be friction associated with the boundary movement. Thus, entropy generation takes place due to boundary movements making the process essentially irreversible. Therefore, a positive net boundary work term that won't be recovered per each thermodynamic cycle is present. In addition to work, excess thermal energy of the system can cross the system boundaries in form of heat, $Q_{\text {out }} . E_{\text {in }}$ is the energy input of the system. The energy balance for a transporter protein, which is the control volume, can be written as

$$
\Delta E_{\text {system }}=E_{\text {in }}-W_{\text {useful }}-W_{\text {boundary }}-Q_{\text {out }}
$$

Since the transporter protein undergoes a thermodynamic/mechanic cycle to perform its function and returns to its initial state at the end of each cycle, the change of the system's energy becomes zero, $\Delta E_{\text {system }}=0$. Thus, the energy balance can be written as

$W_{\text {useful }}=E_{\text {in }}-Q_{\text {out }}-W_{\text {boundary }}$

Based on Eq.2, the thermodynamic first law efficiency

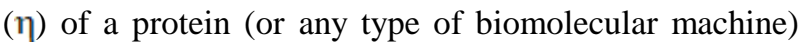
can be defined as (Cengel and Boles, 2008).

$$
\eta=\frac{\text { Desired work output }}{\text { Energy input }}=\frac{W_{\text {useful }}}{E_{\text {in }}}
$$




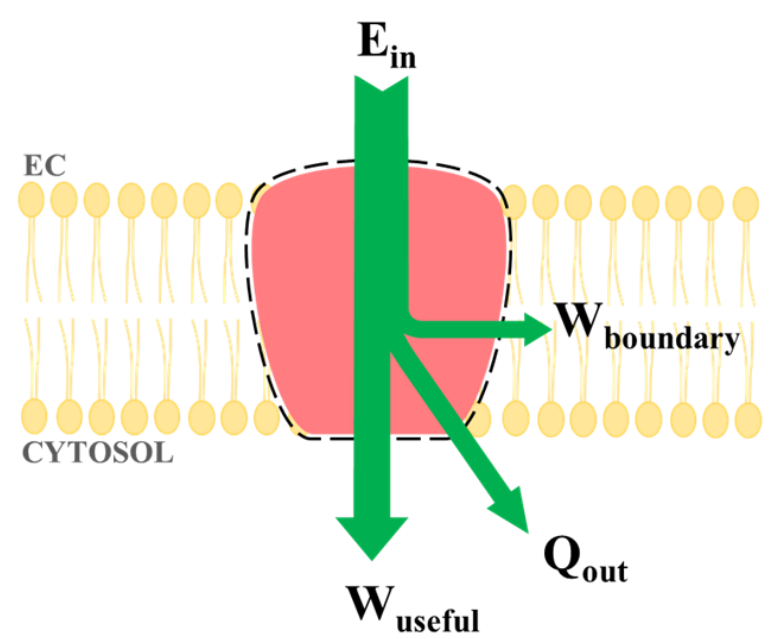

Figure 2. The first law analysis performed on a transporter protein. Part of the energy supplied to the protein is converted to boundary work and useful work. The remaining energy is dissipated to the environment in the form of heat. A transporter protein and phospholipid bilayer are shown schematically in pink and yellow, respectively. Boundary of the control volume is shown with dashed line. Direction of the arrow indicates if the system is gaining (inward) or losing (outward) energy.

\section{Secondary Active Transport across the Membrane}

The reversible work required to transport a molecule/ion from the extracellular medium (EC) to the intracellular (IC) medium can be formulated as follows

$W_{\text {reversible }}=\Delta G_{A}=G_{A}(I C)-G_{A}(E C)$

Here, $G_{A}(I C)$ and $G_{A}(E C)$ are the Gibbs free energies of a single molecule/ion A, being located in the IC and EC medium, respectively. The Gibbs free energy difference $\Delta G_{A}$ in Eq.4 can be defined as (Lodish, 2016)

$\Delta G_{A}=R T \ln \left(\frac{[A]_{I C}}{[A]_{E C}}\right)+Z_{A} \mathcal{F} \Delta \Psi$

The first term is the chemical potential difference due to the difference of molecule/ion concentrations $[A]_{I C}$ and $[A]_{E C}$ of the IC and EC sides of the membrane. The second term is the reversible electric work required to transport a molecule/ion having ionic charge $Z_{A}$ across an electric potential difference $\Delta \Psi$ (membrane potential). $\mathrm{R}$ is universal gas constant $\left(8.314 \mathrm{~J} \mathrm{~K}^{-1} \mathrm{~mol}^{-1}\right), \mathrm{T}$ is temperature $(310 \mathrm{~K})$, and $\mathrm{F}$ is Faraday constant (96845 J $\left.\mathrm{V}^{-1} \mathrm{~mol}^{-1}\right)$.

Based on the second law of thermodynamics, the actual work required to transport a molecule/ion across the membrane performed will be always greater or equal to the reversible work, $W_{\text {useful }} \geq W_{\text {reversible }}$ (Cengel and Boles, 2008). The lower limit for work values, which is $W_{\text {useful }}=W_{\text {reversible }}$, will be applied in our calculations as there is currently no completely reliable way to calculate the actual (irreversible) work values per cycle. Transporter proteins may cotransport molecules/ions against their electrochemical gradient. Thus, the total useful work per cycle is the summation of all the useful works performed for the transport of each molecule/ion, $i=\{A, B, \ldots\}$ and can be formulated as follows

$W_{\text {useful }}=\sum_{i} \Delta G_{i}=\sum_{i}\left(R T \ln \left(\frac{[\hat{i}]_{I C / E C}}{[\hat{i}]_{E C / I C}}\right)+Z_{i} \mathcal{F} \Delta \Psi\right)_{(6)}$

The energy input to the system as a result of the movement of a molecule/ion A down its electrochemical gradient can be estimated by their free energy difference $\Delta G_{A}$ as formulated by Eq.5. Thus, the total energy input per cycle due to the transport of all molecules/ions down their electrochemical gradient becomes

$E_{\text {in }}=\sum_{i} \Delta G_{i}=\sum_{i}\left(R T \ln \left(\frac{[i]_{I C / E C}}{[\dot{i}]_{E C / I C}}\right)+Z_{i} \mathcal{F} \Delta \Psi\right)$

\section{RESULTS AND DISCUSSION}

\section{Ion Concentrations in Neurons, Astrocytes, and Synaptic Clefts}

The IC concentrations of $\mathrm{K}^{+}, \mathrm{Na}^{+}$, and $\mathrm{Cl}^{-}$in neurons are $140 \mathrm{mM}, 5-15 \mathrm{mM}$, and, 4-30 $\mathrm{mM}$, respectively, while their respective EC concentrations are $5 \mathrm{mM}, 145 \mathrm{mM}$, and $110 \mathrm{mM}$ (Alberts, 2002). The resting membrane potential of a neuron is approximately $-70 \mathrm{mV}$ (Betts et al., 2013). As the $\mathrm{K}^{+}$selectivity of astrocyte membranes is higher than that of neurons, resting membrane potentials are more negative $(-90 \mathrm{mV})$ in astrocytes. EC concentration of $\mathrm{K}^{+}$in astrocytes is normally low, around 3-5 mM and IC concentrations of $\mathrm{K}^{+}$are about 108-110 $\mathrm{mM}$ (Orkand, 1986). Baseline IC concentration of $\mathrm{Na}^{+}$in astrocytes is about $15 \mathrm{mM}$ and $\mathrm{EC}$ concentration of $\mathrm{Na}^{+}$ in astrocytes is around $120 \mathrm{mM}$ (Orkand, 1986; Rose, 1997).

\section{EAAT Shows Higher First Law Efficiency for Glutamate than Aspartate Transport}

EAATs transport acidic or neutral amino acids such as glutamate and aspartate into neurons and astrocytes (Gesemann et al., 2010; Zomot and Bahar, 2013; Cater et al., 2014). In each thermodynamic cycle of EAATs, a single glutamate/aspartate is transported from the EC side into IC side. Glutamate/aspartate is cotransported with $3 \mathrm{Na}^{+}$and $1 \mathrm{H}^{+}$(Vandenberg and Ryan, 2013; Cater et al., 2014). After release of amino acid into the cell, $\mathrm{K}^{+}$ binds to the EAAT and is transported out of the cell (Landowski et al., 2007). IC glutamate concentration in neurons ranges between 5-10 mM (Featherstone, 2009; Schwartzkroin, 2009) and is generally taken as $10 \mathrm{mM}$ (Kanai and Hediger, 2004; Jong and O'Malley, 2017). In the synaptic cleft, EC concentration of glutamate can reach up to $1 \mathrm{mM}$ upon signal transition, and later falls down to $\sim 25 \mathrm{nM}$ due to uptake by neurons and astrocytes (Herman and Jahr, 2007). For aspartate, on the other hand, there is a scarcity in information regarding to what extend its concentration change upon signal transition. The IC concentration of aspartate in neurons was 
reported as 2-4 $\mathrm{mM}$, whereas its EC concentration was reported to be about $2 \mu \mathrm{M}$ (Erecińska et al., 1983). The processes for glutamate and aspartate transports can be represented by (Figure3A)

$G L U_{E C}+3 N a_{E C}^{+}+K_{I C}^{+} \rightarrow G L U_{I C}+3 N a_{I C}^{+}+K_{E C}^{+}$ and

$A S P_{E C}+3 N a_{E C}^{+}+K_{I C}^{+} \rightarrow A S P_{I C}+3 N a_{I C}^{+}+K_{E C}^{+}$,

respectively.

First law efficiency of EAAT will be calculated for the basal levels of neurotransmitters, which corresponds to the maximum work output operational condition of EAAT and hence provides an upper limit for EAAT efficiency. The required energy for each thermodynamic cycle of the EAAT in neurons is provided by the flow of $3 \mathrm{Na}^{+}$ions $(\mathrm{EC} \rightarrow \mathrm{IC})$ and $1 \mathrm{~K}^{+}$ion $(\mathrm{IC} \rightarrow \mathrm{EC})$. Thus, the energy input to the system by the ion flow is calculated as follows:

$\Delta G_{N a^{+}}=R T \ln \left(\frac{\left[N a_{I C}^{+}\right]}{\left[N a_{E C}^{+}\right]}\right)+Z \mathcal{F} \Delta \Psi=-12.63 \mathrm{~kJ} / \mathrm{mol}$

$\Delta G_{K^{+}}=R T \ln \left(\frac{\left[K_{E C}^{+}\right]}{\left[K_{I C}^{+}\right]}\right)+Z \mathcal{F} \Delta \Psi=-1.83 \mathrm{~kJ} / \mathrm{mol}$

The total energy input for a single EAAT cycle becomes $E_{\text {in }}=\left(-3 \Delta G_{N a^{+}}\right)+\left(-\Delta G_{K^{+}}\right)=37.88+1.80=39.68 \mathrm{~kJ} / \mathrm{mol}$ in neurons. For the glutamate, as reported in our earlier study (Gur et al., 2019), the useful work per EAAT is transport of glutamate into neurons and it can be evaluated as

$W_{\text {useful }}=\Delta G_{G L U}=R T \ln \left(\frac{\left[G L U_{I C}\right]}{\left[G L U_{E C}\right]}\right)+Z \mathcal{F} \Delta \Psi=33.25 \mathrm{~kJ} / \mathrm{mol}$

For the other substrate aspartate, the useful work per EAAT in neurons can be evaluated as $W_{\text {useful }}=\Delta G_{\text {ASP }}=17.80 \mathrm{~kJ} / \mathrm{mol}$. Based on these values, maximum efficiency of EAAT per functional cycle becomes $\eta=0.85$ (85\%) for glutamate (Gur et al., 2019) and $\eta=0.45$ for aspartate.

\section{ASCT2 First Law Efficiency Can Be as high as $\sim 80 \%$}

ASCT2 carries out the $\mathrm{Na}^{+}$-dependent transport of glutamine by the antiport transport with other neutral amino acids. $\mathrm{Na}^{+}$ion is transported with any of these amino acids in a 1:1 stoichiometry (Oppedisano et al., 2007). ASCT2 effectively regulates the flow of glutamine, allowing glutamine to flow into neuronal microenvironment and removal of extracellular amino acids (Bröer et al., 1999). ASCT2 also function as a glutamine/glutamate exchanger, thus plays a critical role in glutamate-glutamine cycle. The glutamine synthesized in astrocytes is exchanged with glutamate via antiport system of ASCT2 (Schousboe and Sonnewald, 2016). This glutamine/glutamate flow of ASCT2 is observed in astrocytes but not in neurons (Yamamoto et al., 2003). EC glutamine concentrations are very low ranging from 0.13 to $0.5 \mathrm{mM}$, and the IC glutamine concentrations vary in the range 5-10 $\mathrm{mM}$ in neurons and astrocytes (Schousboe and Sonnewald, 2016).

The process for glutamine/glutamate antiport can be represented by (Figure 3B)

$$
G L N_{I C}+N a_{E C}^{+}+G L U_{E C} \rightarrow G L N_{E C}+N a_{I C}^{+}+G L U_{I C} .
$$

For the glutamine/glutamate exchange in astrocytes, the translocation of $1 \mathrm{Na}^{+}(\mathrm{EC} \rightarrow \mathrm{IC})$ ion and 1 glutamine $(\mathrm{IC} \rightarrow \mathrm{EC}) \quad$ releases $\Delta G_{\mathrm{Na}}{ }^{+}=14.08 \mathrm{~kJ} / \mathrm{mol} \quad$ and $\Delta G_{G L N}=11.19 \mathrm{~kJ} / \mathrm{mol}$, respectively. Thus, total energy input per cycle becomes $E_{\text {in }}=25.27 \mathrm{~kJ} / \mathrm{mol}$. Via Eq.5, the useful work can be evaluated as $W_{\text {useful }}=\Delta G_{G L U}=19.59 \mathrm{~kJ} / \mathrm{mol}$. Based on these values, ASCT2 operates with efficiency of $\eta=0.78$ in astrocytes. Since, these calculations were performed using the highest concentration gradients of molecules/ions, they represent the maximum efficiency of ASCT2.

\section{$B^{0}$ AT2 Shows High First Law Efficiency for Glutamine Despite of Low-Affinity}

$\mathrm{B}^{0} \mathrm{AT} 2$ is able to transport neutral amino acids such as proline, leucine, isoleucine, valine, and methionine in neurons. Moreover, glutamine, alanine and phenylalanine were low-affinity substrates of these transporter (Bröer et al., 2006). Transport is $\mathrm{Na}^{+}$-dependent, $\mathrm{Cl}^{-}$-independent and electrogenic. $\mathrm{B}^{0} \mathrm{AT} 2$ cotransports one $\mathrm{Na}^{+}$with amino acid. The process for glutamine transport can be represented by $G L N_{E C}+N a_{E C}^{+} \rightarrow G L N_{I C}+N a_{I C}^{+}$(Figure $3 \mathrm{C})$. Useful work of $\mathrm{B}^{0} \mathrm{AT} 2$ is the transport of a single glutamine and is evaluated as $W_{\text {useful }}=\Delta G_{G L N}=11.19 \mathrm{~kJ} / \mathrm{mol}$. The energy input which is provided by transport of $\mathrm{Na}^{+}$becomes $E_{\text {in }}=-\Delta G_{\mathrm{Na}^{+}}=12.63 \mathrm{~kJ} / \mathrm{mol}$. Based on these values the first law efficiency of $\mathrm{B}^{0} \mathrm{AT} 2$ is evaluated as $\eta=0.89$.

\section{SA Transporter Shows Slightly Larger Maximum First Law Efficiency than SN Transporter}

The SA transporter located in neurons and the SN transporter located in astrocyte are two members of the SCL38 family showing slightly different stoichiometry for glutamine transport. While SA transporter cotransports the glutamine with a single $\mathrm{Na}^{+}$ion, $\mathrm{SN}$ transporter includes the antiport of $\mathrm{H}^{+}$ion in addition to the co-transport of $\mathrm{Na}+$ ion and glutamine (Bröer, 2014). The cotransport process of the glutamine via SA transporter can be represented by (Figure 3D) $G L N_{E C}+N a_{E C}^{+} \rightarrow G L N_{I C}+N a_{I C}^{+}$. Useful work per SA transporter cycle, which is the energy required to transport a single glutamine molecule across the cell membrane is $W_{\text {useful }}=\Delta G_{G L N}=11.19 \mathrm{~kJ} / \mathrm{mol}$. The energy input for SA transporter cycle is provided by transport of $\mathrm{Na}^{+}$and is estimated to be $E_{\text {in }}=-\Delta G_{N a^{+}}=12.63 \mathrm{~kJ} / \mathrm{mol}$. Based on these values, a first law efficiency of $\eta=0.89$ for SA transporter is 
obtained. As indicated above, SN transporters have a different stoichiometry. In the literature, $\mathrm{pH}$ levels on both sides of the membrane was taken/assumed identical. Thus, resulting in a zero energy change when an $\mathrm{H}^{+}$is transported across the membrane; $\Delta G_{H^{+}}=0$. The transport process via $\mathrm{SN}$ transporter can be represented by (Figure 3E) $G L N_{E C}+N a_{E C}^{+} \rightarrow G L N_{I C}+N a_{I C}^{+}$. Useful work output of the $\mathrm{SN}$ transporter is the transport of a single glutamine and is evaluated as $W_{\text {useful }}=\Delta G_{G L N}=11.19 \mathrm{~kJ} / \mathrm{mol}$. The energy input for SN transporter cycle which is provided by transport of $\mathrm{Na}^{+}$is evaluated as $E_{\text {in }}=-\Delta G_{N a^{+}}=14.08 \mathrm{~kJ} / \mathrm{mol}$. Based on these values the first law efficiency of $\mathrm{SN}$ transporter becomes $\eta=0.80$.

Forward and Reverse Transport in GABA Transporter Probably Takes Place with Different Efficiencies

GABA uptake via SLC6 family GABA transporters is coupled to the movement of $\mathrm{Na}^{+}$and $\mathrm{Cl}^{-}$across the membrane. Whether the stoichiometry of GABA cotransport with $\mathrm{Na}^{+}$and $\mathrm{Cl}^{-}$ions is $2 \mathrm{Na}^{+}: 1 \mathrm{Cl}^{-}: 1$ GABA or $3 \mathrm{Na}^{+}: 1 \mathrm{Cl}^{-}$: $1 \mathrm{GABA}$ is uncertain, but the recent experimental studies support the predictions of the $3 \mathrm{Na}^{+}: 1 \mathrm{Cl}^{-}$: $1 \mathrm{GABA}$ stoichiometry model (Willford et al., 2015). GABA transporters are able to work in the forward (uptake of GABA) or reverse (release of GABA) mode depending on the direction of the electrochemical driving force (Eskandari et al., 2017). In the forward mode, $\mathrm{Na}^{+} / \mathrm{Cl}^{-} / \mathrm{GABA}$ are cotransported into the cell, resulting the net positive charge movement into the cell. In the reverse mode, $\mathrm{Na}^{+} / \mathrm{Cl}^{-} / \mathrm{GABA}$ are cotransported out of the cell, resulting the net positive charge movement out of the cell. The transport stoichiometry is same for both forward and reverse mode of transport. The IC concentration of GABA is $2 \mathrm{mM}$ in neurons and the EC concentration of GABA is 0.1 to $2.9 \mu \mathrm{M}$ in GABAergic synapse (Chen and Huang, 2014, Eskandari, Willford et al., 2017). The process can be represented by (Figure 3F)

$G A B A_{E C}+3 N a_{E C}^{+}+C l_{E C}^{-} \rightarrow G A B A_{I C}+3 N a_{I C}^{+}+C l_{I C}^{-}$ $G A B A_{I C}+3 N a_{I C}^{+}+C l_{I C}^{-} \rightarrow G A B A_{E C}+3 N a_{E C}^{+}+C l_{E C}^{-}$

for the forward and reverse modes, respectively.

In the forward mode, the translocation of $3 \mathrm{Na}^{+}$ions $(\mathrm{EC} \rightarrow \mathrm{IC})$ across the membrane of a neuron releases $E_{\text {in }}=-3 \Delta G_{\mathrm{Na}^{+}}=37.88 \mathrm{~kJ} / \mathrm{mol}$ of energy. The useful work per GABA transporter cycle can be calculated as $\Delta G_{G A B A}+\Delta G_{C l^{-}}=25.52+3.43=28.95 \mathrm{~kJ} / \mathrm{mol}$.
Based on these values, GABA transporters operates with an efficiency of $\eta=0.76$ in forward mode in neurons. The thermodynamic first law efficiency of the reverse mode, assuming that $3 \mathrm{Na}^{+}$ions per reverse cycle are transported, gives an efficiency value larger than $100 \%$, which is thermodynamically not possible. Since the thermodynamic first law efficiency was defined as the useful work output divided by the energy input, this would indicate that either less work output is performed or there is an additional energy input. As was indicated earlier, it is reported in the literature that GABA transporter might translocate $2 \mathrm{Na}^{+}$ions per GABA. Assuming this is correct, the thermodynamic first law efficiency of the reverse mode would be $91 \%$. Another possibility would be that the reverse transport takes place at higher IC or lower EC GABA concentrations, which would be in accord with the literature as it was reported that the GABA transport direction depends on the direction of the electrochemical driving force (Eskandari et al., 2017). Similarly, the reverse mode might take place under different ion concentrations than basal conditions.

\section{First Law Efficiencies Change with Neurotransmitter Concentrations}

Upon a signal arrival, neurotransmitters are released from presynaptic neurons to synapse and activate receptors and channels on postsynaptic neurons. Through this flow, signal becomes chemically transmitted to the postsynaptic neurons. As a result of neurotransmitter release and uptake by transporters, the concentrations of neurotransmitters in synapse rise above and fall below basal levels, respectively, while intracellular neurotransmitter levels remain relatively stable. Ion concentrations in the neurons and synapse are not considerably affected by this process (Lodish, 2016; Gur et al., 2019). Change of synaptic neurotransmitter levels affects the thermodynamic first law efficiencies of the transporters. During signal transduction neurotransmitter levels in synapse are elevated, resulting in higher transporter uptake operating efficiencies compared to their efficiencies at basal neurotransmitter levels. During signal recovery, on the other hand, neurotransmitter levels in synapse are low, resulting in lower transporter uptake operating efficiencies compared to those at basal neurotransmitter levels. Changes in first law efficiencies of transporters involved in GGC with respect to their transported neurotransmitter concentrations are depicted in Figure 4. 


\section{A) EAAT (Neuron)}

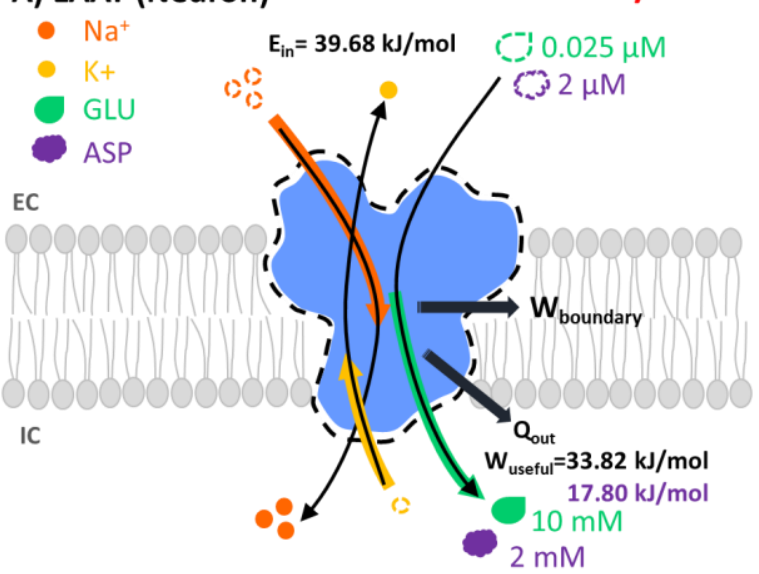

C) $\mathrm{B}^{0} \mathrm{AT} 2$ (Neuron)
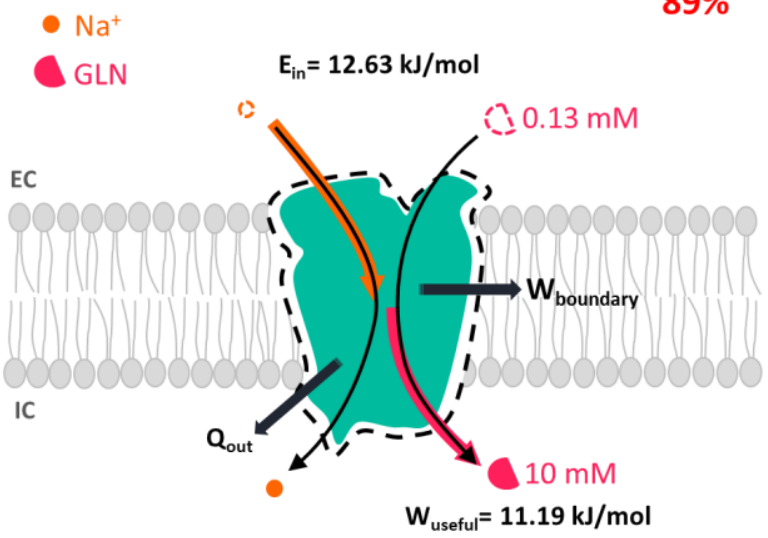

E) SN (Astrocyte)

- $\mathrm{Na}^{+}$

- $\mathrm{H}^{+}$

GLN

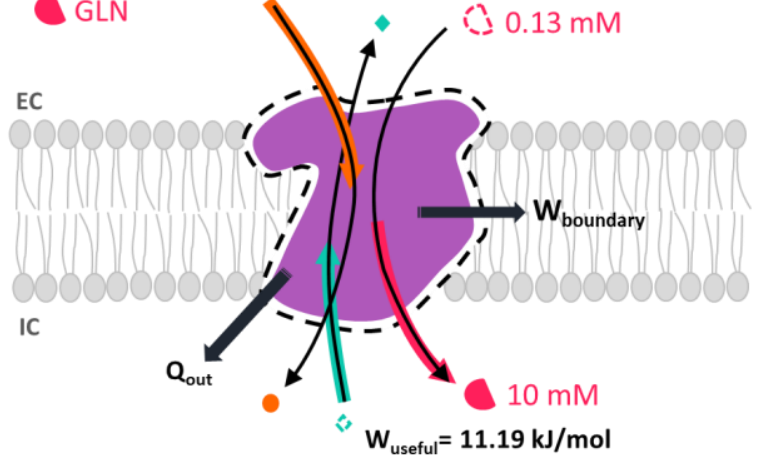

B) ASCT2 (Astrocyte)

$78 \%$

$$
\begin{array}{ll}
\mathrm{Na}^{+} & \mathrm{E}_{\text {in }}=\mathbf{2 5 . 2 7} \mathbf{~ k J} / \mathbf{m o l} \\
\mathrm{GLN} &
\end{array}
$$

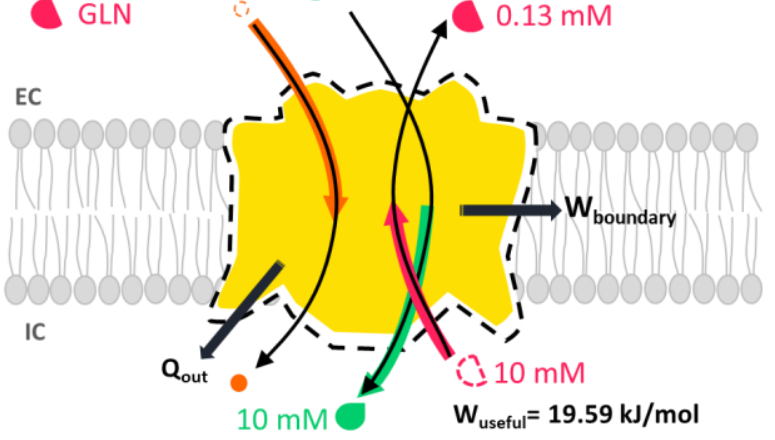

D) SA (Neuron)
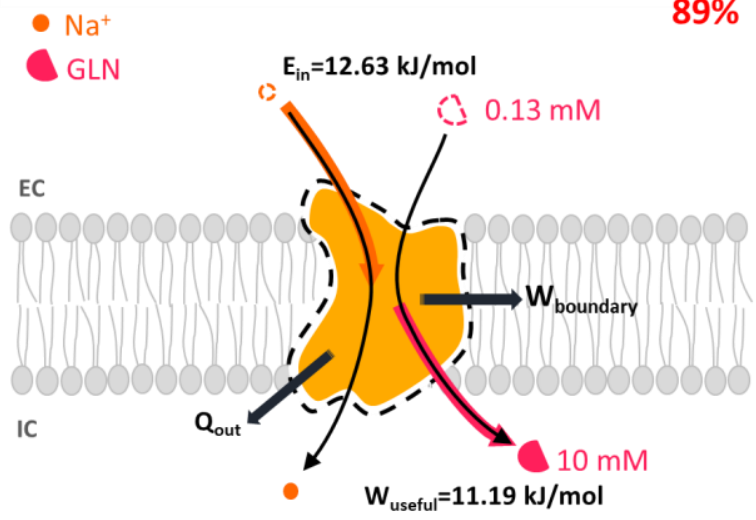

F) GAT (Neuron)

$76 \%$

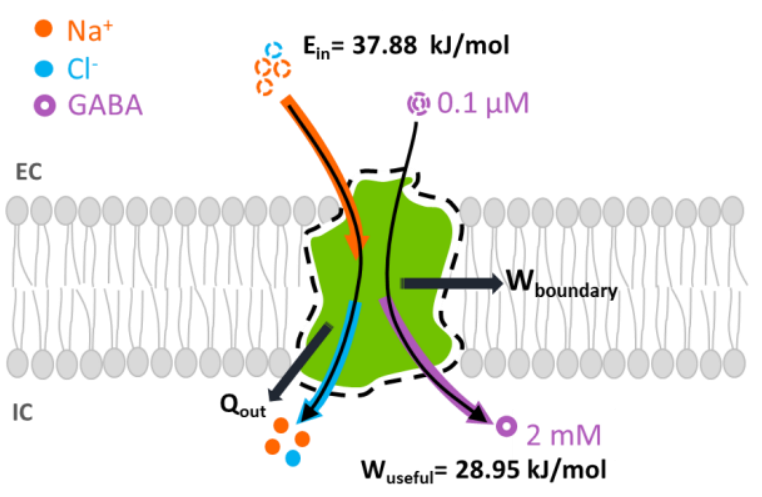

Figure 3. The first law analysis of transporters involved in GGC. Each protein is schematically shown based on their crystal structure. Boundary of the control volume defining the thermodynamic system is shown with a dashed line. Thin arrows represent the direction of transport. 


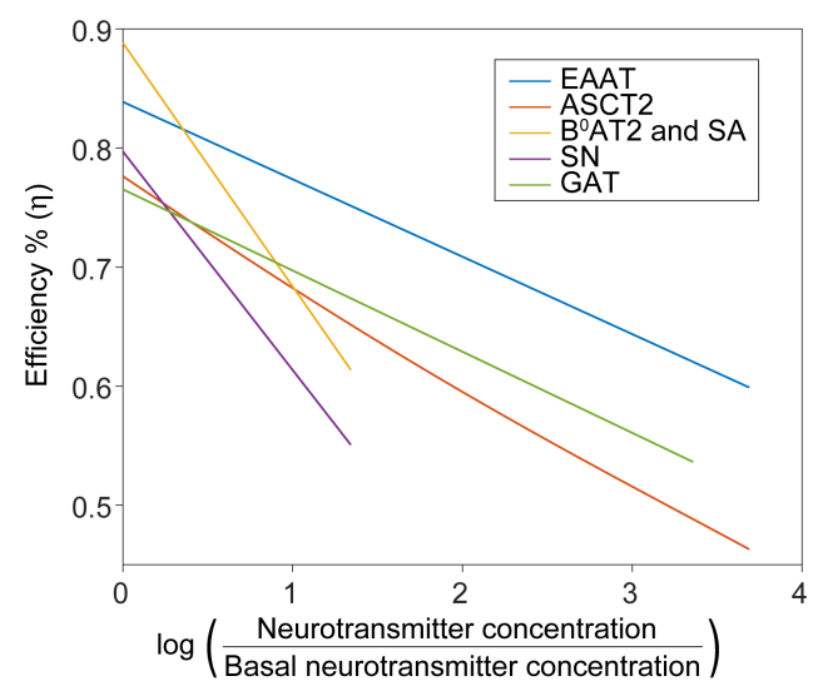

Figure 4: Change in transporter first law efficiencies with respect to neurotransmitter concentrations in the synapse. Glutamate (blue and red), glutamine (yellow and purple), and GABA (green) concentrations were normalized with respect to their basal levels.

\section{CONCLUSIONS}

The first law of thermodynamics analysis was performed for the following set of biomolecular machines involved in the GGC; EAAT, ASCT2, $\mathrm{B}^{0} \mathrm{AT} 2, \mathrm{SA}, \mathrm{SN}$, and GABA transporters. For the first time in literature, the thermodynamic first law efficiencies of these transporters were reported. First law efficiencies were observed to change with respect to the neurotransmitter concentrations in the synapse and maximum efficiencies for EAAT (for glutamate transport), ASCT2, $\mathrm{B}^{0} \mathrm{AT} 2$, $\mathrm{SA}, \mathrm{SN}$, and GABA (forward mode) transporters were evaluated to be in the range of $85 \%, 78 \%, 89 \%, 89 \%$, $80 \%$, and $76 \%$. With the increase of neurotransmitter concentrations in the synapse, first law efficiencies drop to $60 \%, 46 \%, 61 \%, 61 \%, 55 \%$, and $54 \%$ for EAAT (for glutamate transport), ASCT2, $\mathrm{B}^{0} \mathrm{AT} 2$, SA SN, GABA (forward mode) respectively. Interestingly, transport of glutamate in EAAT was observed to take place with a maximum efficiency of $85 \%$, while aspartate transport in EAAT was evaluated to take place with a maximum efficiency of $45 \%$. This is a very important finding as it potentially indicates that transporter operational efficiencies depend on the substrate they transport. This, in turn, suggests the possibility of transporters to be optimized for the transport of a specific substrate. In addition to the investigated neurotransmitter transports in this study, ASCT2 can transport neutral amino acids; $\mathrm{B}^{0} \mathrm{AT} 2$ can transport proline, leucine, isoleucine, valine, methionine, alanine and phenylalanine; SA transporters can transport alanine; SN transporters can transport asparagine, histidine, alanine and serine. However, there is scarcity in the literature regarding the ion and substrate concentrations in synapses, neurons, and astrocytes. Thus, making it very difficult to perform the first law of thermodynamics analysis for these transport processes. Further research and data collection have to be performed to further investigate the thermodynamic efficiencies of transporters for various transported substrates, and investigate if transporters are indeed optimized for a specific substrate transport.

Our study shows that transporters involved in GGC are able to operate at much higher energy conversion efficiencies than the internal combustion engines we encounter in daily life, which typically operate at $25-30 \%$ efficiencies. Identifying such bio-nanomachines operating at high efficiencies and understanding their machinery could provide critical design parameters for engineering novel synthetic nanomachines and also reveal the possibility to repurpose them for nanotechnological applications.

\section{REFERENCES}

Alberts B., 2002, Membrane transport of small molecules and the electrical properties of membranes, Molecular biology of the cell, 615-657.

Bak L. K., Schousboe A. and Waagepetersen H. S., 2006, The glutamate/GABA-glutamine cycle: aspects of transport, neurotransmitter homeostasis and ammonia transfer, Journal of neurochemistry, 98,3, 641-653.

Betts J., Desaix P., Johnson E., Johnson J., Korol O., Kruse D., Poe B., Wise J., Womble M. and Young K., 2013, OpenStax College \& Rice University, Anatomy \& physiology.

Bhutia Y. D. and Ganapathy V., 2016, Glutamine transporters in mammalian cells and their functions in physiology and cancer, Biochimica et Biophysica Acta (BBA)-Molecular Cell Research, 1863,10, 2531-2539.

Bröer A., Brookes N., Ganapathy V., Dimmer K. S., Wagner C. A., Lang F. and Bröer S., 1999, The astroglial ASCT2 amino acid transporter as a mediator of glutamine efflux, Journal of neurochemistry, 73,5, 21842194.

Bröer A., Tietze N., Kowalczuk S., Chubb S., Munzinger M., Bak L. K. and Bröer S., 2006, The orphan transporter v7-3 (slc6a15) is a Na+-dependent neutral amino acid transporter (B0AT2), Biochemical Journal, 393,1, 421-430.

Bröer S., 2014, The SLC38 family of sodium-amino acid co-transporters, Pflügers Archiv-European Journal of Physiology, 466,1, 155-172.

Cabrera-Pastor A., Arenas Y. M., Taoro-Gonzalez L., Montoliu C. and Felipo V., 2019, Chronic hyperammonemia alters extracellular glutamate, glutamine and GABA and membrane expression of their transporters in rat cerebellum. Modulation by extracellular cGMP, Neuropharmacology, 161, 107496. 
Cater R. J., Vandenberg R. J. and Ryan R. M., 2014, The domain interface of the human glutamate transporter EAAT1 mediates chloride permeation, Biophysical journal, 107,3, 621-629.

Cengel Y. A. and Boles M. A., 2008, Thermodynamics: An Engineering Approach, McGraw-Hill.

Chen Z. L. and Huang R. Q., 2014, Extracellular pH modulates GABAergic neurotransmission in rat hypothalamus, Neuroscience, 271, 64-76.

Danbolt N. C., 2001, Glutamate uptake, Progress in neurobiology, 65,1, 1-105.

Danbolt N. C., Furness D. N. and Zhou Y., 2016, Neuronal vs glial glutamate uptake: resolving the conundrum, Neurochemistry international, 98, 29-45.

Erecińska M., Wantorsky D. and Wilson D. F., 1983, Aspartate transport in synaptosomes from rat brain, Journal of Biological Chemistry, 258, 15, 9069-9077.

Eskandari S., Willford S. L. and Anderson C. M., 2017, Revised ion/substrate coupling stoichiometry of GABA transporters, Glial Amino Acid Transporters, Springer.

Featherstone D. E., 2009, Intercellular glutamate signaling in the nervous system and beyond, ACS chemical neuroscience, 1,1, 4-12.

Gesemann M., Lesslauer A., Maurer C. M., Schönthaler H. B. and Neuhauss S. C., 2010, Phylogenetic analysis of the vertebrate excitatory/neutral amino acid transporter (SLC1/EAAT) family reveals lineage specific subfamilies, BMC evolutionary biology, 10,1, 117.

Gur M., Golcuk M., Yilmaz S. Z. and Taka E., 2019, Thermodynamic first law efficiency of membrane proteins, Journal of biomolecular structure \& dynamics, 1.

Heckel T., Bröer A., Wiesinger H., Lang F. and Bröer S., 2003, Asymmetry of glutamine transporters in cultured neural cells, Neurochemistry International, 43,4, 289298.

Herman M. A. and Jahr C. E., 2007, Extracellular glutamate concentration in hippocampal slice, Journal of Neuroscience, 27,36, 9736-9741.

Höglund P. J., Nordström K. J., Schiöth H. B. and Fredriksson R., 2010, The solute carrier families have a remarkably long evolutionary history with the majority of the human families present before divergence of Bilaterian species, Molecular biology and evolution, 28,4, 1531-1541.

Jong Y.-J. I. and O’Malley K. L., 2017, Mechanisms associated with activation of intracellular metabotropic glutamate receptor, mGluR5, Neurochemical research, $42,1,166-172$.

Kanai Y., Clémençon B., Simonin A., Leuenberger M., Lochner M., Weisstanner M. and Hediger M. A., 2013, The SLC1 high-affinity glutamate and neutral amino acid transporter family, Molecular aspects of medicine, 34,23, 108-120.

Kanai Y. and Hediger M. A., 2004, The glutamate/neutral amino acid transporter family SLC1: molecular, physiological and pharmacological aspects, Pflügers Archiv, 447,5, 469-479.

Kjelstrup S., De Meis L., Bedeaux D. and Simon J.-M., 2008, Is the Ca 2+-ATPase from sarcoplasmic reticulum also a heat pump?, European Biophysics Journal, 38,1, 59-67.

Landowski C., Suzuki Y. and Hediger M., 2007, Transporters for Excitatory and Neutral Amino Acids, Handbook of Neurochemistry and Molecular Neurobiology: Neural Membranes and Transport, 305323.

Lin L., Yee S. W., Kim R. B. and Giacomini K. M., 2015, SLC transporters as therapeutic targets: emerging opportunities, Nature reviews Drug discovery, 14,8, 543.

Lodish H. F., 2016, Transmembrane Transport of Ions and Small Molecules, Molecular Cell Biology, 8th Ed W. H. Freeman and Company.

Nakanishi T., Kekuda R., Fei Y.-J., Hatanaka T., Sugawara M., Martindale R. G., Leibach F. H., Prasad P. D. and Ganapathy V., 2001, Cloning and functional characterization of a new subtype of the amino acid transport system N, American Journal of PhysiologyCell Physiology, 281,6, C1757-C1768.

Oppedisano F., Pochini L., Galluccio M. and Indiveri C., 2007, The glutamine/amino acid transporter (ASCT2) reconstituted in liposomes: transport mechanism, regulation by ATP and characterization of the glutamine/glutamate antiport, Biochimica et Biophysica Acta (BBA)-Biomembranes, 1768,2, 291-298.

Orkand R. K., 1986, Introductory remarks: Glial-interstitial fluid exchange, Annals of the New York Academy of Sciences, 481,1, 269-272.

Ortega A. and Schousboe A., 2017, Glial Amino Acid Transporters, Springer International Publishing.

Owens D. F. and Kriegstein A. R., 2002, Is there more to GABA than synaptic inhibition?, Nature Reviews Neuroscience, 3,9, 715 .

Pinilla-Tenas J., Barber A. and Lostao M., 2003, Transport of proline and hydroxyproline by the neutral 
amino-acid exchanger ASCT1, The Journal of membrane biology, 195,1, 27-32.

Pramod A. B., Foster J., Carvelli L. and Henry L. K., 2013, SLC6 transporters: structure, function, regulation, disease association and therapeutics, Molecular aspects of medicine, 34,2-3, 197-219.

Rose C. R., 1997, Intracellular Na+ regulation in neurons and glia: functional implications, The Neuroscientist, 3,2, $85-88$.

Sakai K., Shimizu H., Koike T., Furuya S. and Watanabe M., 2003, Neutral amino acid transporter ASCT1 is preferentially expressed in L-Ser-synthetic/storing glial cells in the mouse brain with transient expression in developing capillaries, Journal of Neuroscience, 23,2, $550-560$

Schlessinger A., Yee S. W., Sali A. and Giacomini K. M., 2013, SLC classification: an update, Clinical Pharmacology \& Therapeutics, 94,1, 19-23.

Schousboe A., Sarup A., Bak L., Waagepetersen H. and Larsson O., 2004, Role of astrocytic transport processes in glutamatergic and GABAergic neurotransmission, Neurochemistry international, 45,4, 521-527.

Schousboe A. and Sonnewald U., 2016, Glutamate/gabaglutamine Cycle, Springer.

Schwartzkroin P. A., 2009, MRS,Encyclopedia of Basic Epilepsy Research, Elsevier Science.
Vandenberg R. J. and Ryan R. M., 2013, Mechanisms of glutamate transport, Physiological reviews, 93,4, 16211657.

Walls A. B., Waagepetersen H. S., Bak L. K., Schousboe A. and Sonnewald U., 2015, The glutamineglutamate/GABA cycle: Function, regional differences in glutamate and GABA production and effects of interference with GABA metabolism, Neurochemical research, 40,2, 402-409.

Willford S. L., Anderson C. M., Spencer S. R. and Eskandari S., 2015, Evidence for a revised ion/substrate coupling stoichiometry of GABA transporters, The Journal of membrane biology, 248,4, 795-810.

Yamamoto T., Nishizaki I., Furuya S., Hirabayashi Y., Takahashi K., Okuyama S. and Yamamoto H., 2003, Characterization of rapid and high-affinity uptake of Lserine in neurons and astrocytes in primary culture, FEBS Letters, 548,1-3, 69-73.

Zhou Y. and Danbolt N., 2014, Glutamate as a neurotransmitter in the healthy brain, Journal of neural transmission, 121,8, 799-817.

Zimmermann E. and Seifert U., 2012, Efficiencies of a molecular motor: a generic hybrid model applied to the F1-ATPase, New Journal of Physics, 14,10, 103023

Zomot E. and Bahar I., 2013, Intracellular gating in an inward-facing state of aspartate transporter $\mathrm{GltPh}$ is regulated by the movements of the helical hairpin HP2, Journal of Biological Chemistry, 288,12, 8231-8237.

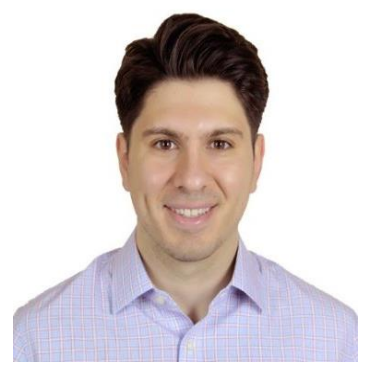

Assoc. Prof. Mert Gur, earned his Bachelor's degree from the Department of Mechanical Engineering Department at Middle East Technical University in 2006 and his $\mathrm{PhD}$ degree in Computational Science and Engineering at Koç University in 2010. Following his graduation, he started working as a postdoctoral associate in the Department of Computational and Systems Biology at the University of Pittsburgh's School of Medicine. During his time in this position, he became jointly appointed as a Lecturer in the Department of Mechanical Engineering and Material Science of the same university. In 2014, Dr. Gur joined the Joint Center for Artificial Photosynthesis (JCAP) at Lawrence Berkeley National Laboratory as a postdoctoral fellow. In 2015, he was appointed as a Faculty member at the rank of assistant professor in the Istanbul Technical University Faculty of Mechanical Engineering. He worked as a visiting faculty scholar in the Department of Computational and Systems Biology at the University of Pittsburgh's School of Medicine in 2016. Mert Gur performed research as a visiting scholar in the Chemistry Department at UC Berkeley in 2017. Dr. Gur was appointed as the Vice Dean of Graduate School of Science, Engineering and Technology in 2018 and as the Vice Dean of Faculty of Mechanical Engineering in 2020, respectively. Since 2019, he is also acting as the Advisory Committee Member and Business Development Advisor to the Director of National High-Performance Computing Center (UHeM). So far, he has published two book chapters and 27 journal papers including Nature, Nature Communications, JBC, JCP, BJ, EBioMedicine and PLoS Bio. Mert Gur joined the editorial board of Journal of Molecular Graphics and Modelling in 2016. Mert Gur was elected to receive the Turkish Academy of Sciences (TÜBA) Outstanding Young Scientist (GEBİP) Award in 2016. 

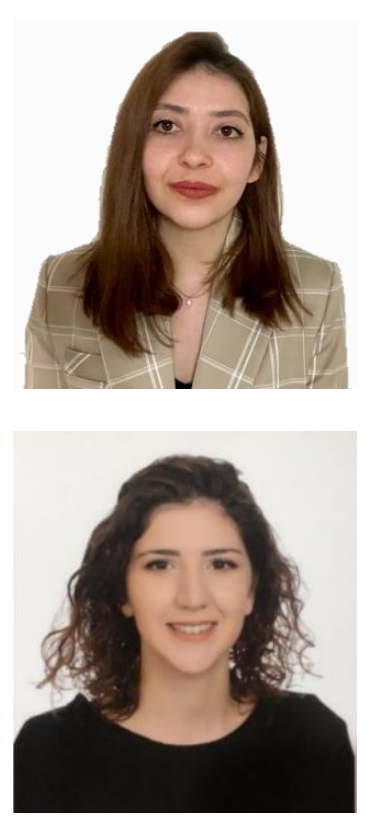

Sema Zeynep Yilmaz, M.Sc., received her B.Sc. and M.Sc. degree in Molecular Biology and Genetics in Atatürk University and in Molecular Biology-Genetics and Biotechnology in Istanbul Technical University at 2016 and 2020, respectively. In her master's thesis, she studied about investigation of thermodynamic properties of leucine transporters and dynein motor proteins using molecular dynamics simulations. Presently, she is a Ph.D. student in Molecular Biology-Genetics and Biotechnology in Istanbul Technical University. She presently continues her Ph.D. studies about the molecular dynamic simulations of cell penetrating peptides.

Elhan Taka, M.Sc., completed her B.Sc. degree in Genetics and Bioengineering in Istanbul Bilgi University at 2017, and M.Sc. degree in Molecular Biology-Genetics and Biotechnology in Istanbul Technical University at 2020. Her master's thesis is titled "Thermodynamic analyses of membrane proteins and Dynein-ATP interaction". Currently, she is a Ph.D. student in Istanbul Technical University, Molecular Biology-Genetics and Biotechnology Graduate Program. She currently continues her studies about the CHK2 and Muts $\alpha$ proteins which are critically involved in colon and breast cancer. 